\title{
Mother Ireland, Blood-Mother, and the Lost Young Men In Selections of Modern Irish Fiction
}

\author{
Dr. Salwa EL-Shazli \\ Assistant professor of English literature and criticism \\ Badr University, School of Linguistics and Translation
}

\begin{abstract}
This paper examines the crisis of three Irish young men whose lives are devastated by both their motherland and blood-mother. The discussion of this paper will be into three areas. First, how Ireland itself is portrayed as a fragile, subjugated female figure in several Irish literary works. Second, the attributes of three Irish mothers as mirroring the image of Ireland itself. Third, the dilemma of three Irish young men as products of both motherland and blood- mother. The scope of discussion will be on Cormac in O'Faolain's No Country for Young Men, Willie in Trevor's Fools of Fortune and $\mathrm{Cal}$ in Mac Laverty's Cal. Irish people have been victims under the heavy hand of British colonialism. The merciless hand of the arrogant colonizer turned Irish people against each other, with an inner inclination towards sectarianism and animosity. Throughout such bloody history of occupation Ireland has been pictured by both British imperialists and Irish nationalists as a helpless, poor and humiliated female or a mother who is completely overwhelmed by her perpetual miseries, who needs help to be saved. While the British portrayal of Ireland as a weak female seeks to keep Ireland in subjugation, the Irish description of Ireland as a humiliated female aims to motivate the Irish people to defend their country. Such features of mother Ireland are transferred into the blood mothers in the three selected texts. Grainne, Cormac's mother in O'Faolain's No Country for Young Men, is responsible for Cormac's escape where she cares more
\end{abstract}

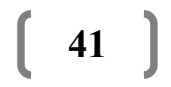


about her womanhood than her motherhood. Also, Eva, Willie's mother in Trevor's Fools of Fortune turns to be a reflection of mother Ireland, a victim of fortune that is full of rage. She, consequently, killed herself with bitterness and despair and led her son into the abyss of loss and escape. Though Cal's mother, Garcia, died when he was young and didn't act as an intensifier to his endless course of loss as in the previous cases, Cal was also victimized and after the burning of his house he stopped to believe in Ireland anymore. Cal's father, who survived the burning of the house, turned out to be like an old female who laments her destiny. So Cal, like Cormac and Willie, couldn't escape loss.

\section{Key terms:}

Motherland-blood-mother- helpless female-Escape-loss.

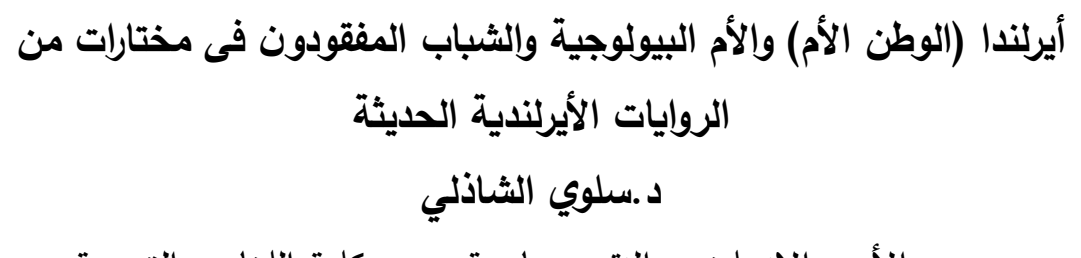

مدرس الأدب الإنجليزي والنقد - جامعة بدر - كلية اللغات والترجمة

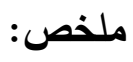

تبحث هذه الورقة في أزمة ثلاثة شبان أيرلنديين تدمرت حياتهم بسبب وطنهم الأم

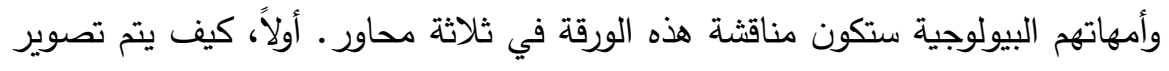

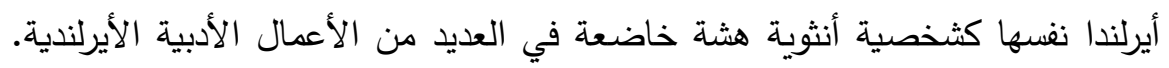

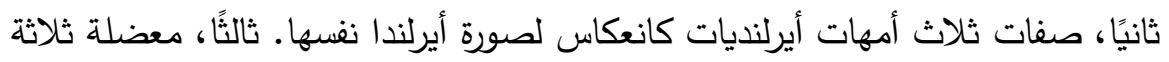

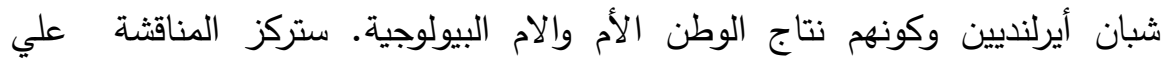

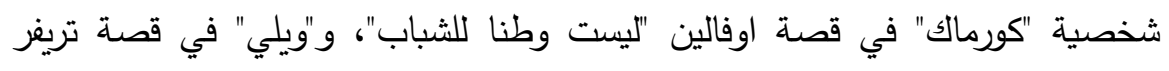

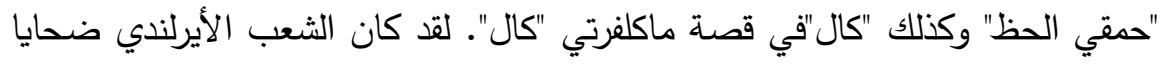

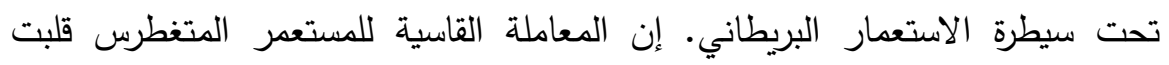


Mother Ireland, Blood-Mother, and the Lost Young Men In Selections of Modern Irish Fiction

Dr. Salwa EL-Shazli

مجلة وادي النيل للاراسات والبحوث الإنسانية والاجتماعية والتربوية (مجلة علمية محكمة)

الثعب الأيرلندي ضد بعضه البعض، بميل داخلي نحو الطائفية والعداء. طوال هذا التاريخ الدموي للاحتلال، صور كل من الإمبرياليين البريطانيين والقوميين الأيرلنديين أيرلندا على أنها امرأة عاجزة وفقيرة ومهانة أو أم غارقة تماءًا في بؤسها الدائم، وتحتاج إلى المساعدة لإنقاذها. في حين يهدف تصوير البريطانيين لأيرلندا على أنها أنثى أنى أنى

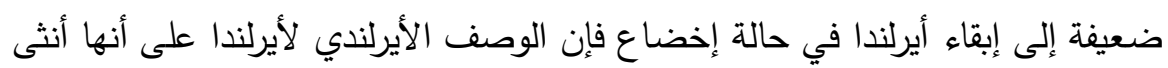

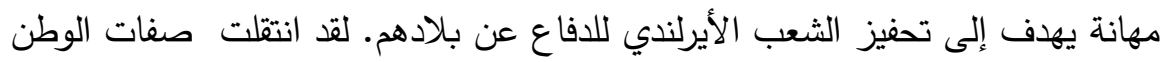
الام إلى الامهات البيولوجيات في النصوص الثلاثة المختارة.

جرين، والدة كورماك في "ليست وطنا للشباب" لأوفالين، هي المسؤولة عن هروب الئلي كورماك حيث تهتم بأنوثتها أكثر من اهتمامها بأمومتها. أيضًا، تتحول إيفا، والدة ويلي في قصة تريغر "حمقي الحظ" إلى انعكاس للوطن الأم، ضحية للقدر الغاضب. ونتيجة

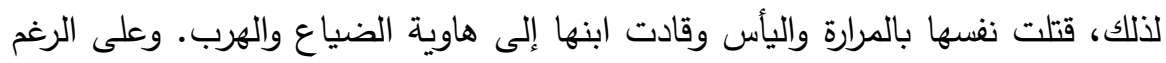
من أن والدة كال، جارسيا، ماتت عندما كان صغيرا ولم تكن بمثابة عامل محفز لمسار ضياعة اللانهائي كما في الحالات السابقة، كان كال ضحية أيضا. وبعد حرق منزله لم

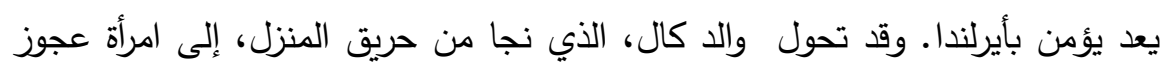
تتدب مصيرها. لذا لم يتمكن كال، مثل كورماك وويلي، من الهروب من الضياع.

الكلمات المفتاحية: الوطن الام- الام البيولوجية- امرأة عاجزة- الهروب- الضياع. 
Escape is an Irish industry, a hope shared by many Irish people. In a country where people are "hunted like wild beasts from bog to glen, scourged by pestilence and famine, subjected to every known cruelty of persecution, perishing by thousands on wintry mountainsides, dying with starved lips stained by the green of grass and nettles" (Creel 198), escape must be longed for and sought as a high priority. In a country which devastates its people, young Irish men, who, sorrowfully, are born and brought up to escape, believe that their Motherland is no longer "a fit place for its people to live in" (O'Toole 24).

The purpose of this essay is to discuss three cases of lost young Irish men, showing how their lives are completely impinged both by their Motherland and blood-mothers. The first part of this paper is devoted to the general image of Ireland as a fractured female land as well as the recurrence of this image in several Irish novels. The second part focuses on the image of Irish women/mothers as reflections of the Motherland. The third part discusses the loss of three young Irish men: Cormac, in Julia O'Faolain's No Country for Young Men, Willie, in William Trevor's Fools of Fortune, and Cal, in Bernard Mac Laverty's Cal.

Irish people, since their early childhood, have been doomed to suffer the heavy burden of religious divisions, political conflicts, partition, and civic strife, not to mention fear, ancient wrongs, and the loathing of each other. Falling under the spell of British control for about eight centuries, the Irish people were "bound in body and starved in mind, living lives ordered by the martial law of an army of occupation" (Creel 189). The Irish, either Catholics or Protestants are, therefore, confined within the strict frame of mutual animosity and, as Deane describe it, "each community sees the other as a threat to its existence...their demonizing of one another as a people naively given to violence, bigotry, and prejudice all combine with economic frailty to produce the sectarian dynamic" (16). Such a society built on and fueled by sectarianism, "kills people because they are Catholic or Protestant, 
republican, nationalist, unionist, terrorist, member of the security forces, or whatever" (Deane 17).

With the existence and daily frequency of such grief, and in terms of gender, Ireland has always been insistently pictured as a female country, a mother completely overwhelmed by her perpetual miseries. Innes points out that: "Throughout the history of its colonization, Ireland has been represented by British Imperialists as well as Irish nationalists and artists as female: She is Hibernia, Eire, Erin, Mother land, the poor old Woman, the Shan Van Vocht, Cathleen ni Houlihan, the Dark Rosaleen." (2) However, if the British portrayal of Ireland as a helpless female was supposed to keep Ireland and the Irish ever in subjugation, the Irish portrayal of Ireland as a poor, humiliated woman was perpetuated to motivate the Irish people to defend their land and to give more blood-sacrifice. In Yeats's "Cathleen ni Houlihan", for instance, "a withered hag walks again like a radiant young queen, but only when young men are willing to kill and die for her in a political insurrection" (Kibred 284-85).

More bitter variations on the same image of Ireland as a broken woman are developed by different writers. In her novel No country for Young Men, Julia O'Faolain portrays Judith Clancy, who represents Ireland, as Laura Vandale notes, as

a harmless, helpless old woman, but she is cursed and carries death with her as a

burden of her past history... a not too hopeful picture is painted of a fractured Ireland,

a country which, like Judith, is caught between the struggles of past and present,

aware that its young men have died before, but unable to control the events leading

them again down the path towards devastation. (25) 
As a reflection of Ireland, Judith's "mind was like her drawers: all confused. Her will was filtering" (O'Faolain 200). Also, in No Country for Young Men, O'Faolain tells us that "nearly half the hospital beds in the country were occupied by mental patients" (122).

In Bernard Mac Laverty's Cal, the image of the Motherland is no less gruesome. Cal says: "people were dying every day, men and women were being crippled and turned into vegetables in the name of Ireland" (Mac Laverty 92), Macella also gives us an account of the poor land: "Ireland. It's like a child. It's only concerned with the past and the present. The future has ceased to exist for it" (131). Again, in William Trevor's Fools of Fortune, Kilneagh, the paradise of the young boy, Willie, is burnt. "In Ireland," Willie tells us, "everything was unsettled and on edge" (Trevor 28). Trevor portrays Ireland as "a country ...fallen to pieces...Gunmen run it now" (142). Due to religious division, the little Imelda "should not be at the convent" because she is "not a Catholic" (156).

Similarly, in Edna O'Brien's The Country Girls Trilogy, Ireland is seen as a land of agony. James Cahalan's statement that "the movement in these three novels is toward increasing exile, loneliness, and loss" forcefully indicates the distressing image of Mother Ireland (59). In this trilogy, O'Brien shows Ireland as "dead and tired and old and crumbling and falling down," analogous to Irish women (120). Ireland is a country where people do not "want to go home" and, as Caithleen/Kate once said: "even at the best of times the house saddened me" (247). In one of her tense speeches with Gillard, Caithleen is asked by him to leave. She replies, "I have nowhere to go" (288). Ironically, Baba's very first sentence in The country girls "still out of order" (5), in which she describes Caithleen's lavatory which does not flush, might suggest the miserable state of Mother Ireland as a whole.

In John McGahern's The Dark, the image of Ireland is quite gloomy, and even the nameless protagonist once asks, "will the morning ever come, ever come" (57). McGahern describes Ireland

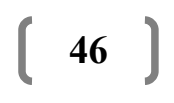


as "no house for reasonableness" (82). Even the Priest's house, the protagonist informs us, is "a green prison. The wall of sycamores shut it away from the road" (63). In McGahern's Ireland there is "uncertain life" and when there is certainty, it is "the certainty of a life based on death" (McGahern 94). The general atmosphere is that of helplessness, loss, and uncertainty, and "everyone's looking for security" (101). The nameless protagonist, unlike his counterpart of McGahern's The Leavetaking, fails to escape as he refuses to be a priest and is also unable to remain in the university. In The Leavetaking, the protagonist is "in an effort to rid himself of his guilt-ridden memories of his mother and of his vow decides to flee Ireland and take refuge in England in the arms of a Protestant American Woman" (LIoyd 7).

In Liam O'Falherty's The black soul, Ireland is still hopeless and morbid. The stranger mentions that "it's awful being alone like this among yokels who only stare with open mouths when a man talks to them" and it is also terrible if one "thought of staying in Dublin among so many people that don't seem to care a damn" (O'Flaherty 34). Like Inverara, Ireland is "the island of defeated peoples" (50). The stranger unfavorably compares his superstitious Motherland to the United States, which is "a great country. None o'yer goddam superstitious there" (38). Also, in O'Flaherty's Going into Exile, two young people, a brother, and a sister, leave Ireland and travel to America. Michael, the son, gives us a brief image of his Motherland, saying: "Sure what did anybody ever get out of the land but poverty and hard work and potatoes and salt?" (96). The two young people "no longer had any place in it [Ireland]...the poverty and sordidness of their home life appeared to them under the aspect of comfort and plenty" (O'Flaherty 101).

The retarded state of Ireland is mournfully described by Norman Vance as a country "notoriously lacking in consensus, where social. Political, religious and cultural dissent is rife" (4). With all these dreadful and suffocating images of their Motherland, the Irish people, young men in particular, have become compelled 
مجلة وادي النيل للاراسات والبحوث الإسانية والاجتماعية والتربوية (مجلة علمية محكمة)

(ISSN : 2536 - 9555)

either to escape and "live as aliens in another land [or] sentenced to a kind of internal exile in their own" (Kibred 337). In a man's life there is a close interconnectedness between the concepts of Motherland and blood-mother. Mother, in general, is the most honored and dignified character in a man's life. She gives love and warmth, and she provides morals and protection. Mother is the first resort in times of woe, the most self-sacrificing creature. With Mother representing this form of unconditional love, what about the concept of man's Motherland? The answer comes briefly in O'Casey's The Plough and the Stars

Clitheroe: You have a mother, Lagon.

Lieut. Lungon: Ireland is greater than a mother.

Capt. Brennan: you have a wife Clitheroe.

Clitheroe: Ireland is greater than a wife. (Act II)

So, what might this suggest about the helpless Irish mothers? In $\mathrm{Cal}$ we see that Cal's mother is his ideal. He remembers her when he needs "self-discipline... she did everything she could do...if she wanted something badly she did it without others; if what she wanted was spiritual, she denied her body...she worked so her family would not want and $\mathrm{Cal}$ had never wanted while she was alive", and her main advice was "turn pain and sorrow into a gift from God" (MacLaverty 116-17). It is she with her "good voice" who first teaches him "rebel songs" (40), and "the only prayer he could say with any sincerity was for the soul of his mother" (40). At last, Garcia, the poor mother, "had collapsed in her own kitchen with a brain haemorrhage" (35).

Caithleen's mother in The country Girls Trilogy "was always a warrior...the best mama in the world...I was everything in the world to her, everything" (6). Like Ireland and most Irish women, "she was dragged down from heavy work, working to keep the place going" (8). Abused by her husband, she was "like a sparrow in the snow, brown and anxious and lonesome" (9). Caithleen, who is completely identified with her poor mother, "felt guilty on and

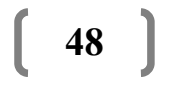


off, because I was so happy with him and because I had seldom seen my mother happy or laughing" (202).

In McGahern's The Dark, the nameless protagonist remembers his dead mother who "had gone away years before and left him" to be physically abused by his violent father (9). "This young boy", Cahalan explains, "is obsessed enough with the loss of his mother to make his earliest conscious ambition the priesthood, so he can say a Mass for her" (63). The protagonist also recounts how she made him happy when "on the road as I came with her from town loaded with parcels" (26).

All these women/mothers are "the lonesome sounds of Ireland" (O'Brien 163). The most lonesome sound is Grainne, Cormac's mother, in No Country for Young Men. She is in a worse position than all the aforementioned helpless mothers. Weekes, in her Irish Women Writers: An Uncharted Tradition, explains that "As a woman, Grainne (of myth and of O'Faolain's novel) is related to Ireland-Mother, Ireland- the "old woman," or "Dark Rosaleen" (180-81).

Grainne has been compelled to be sexually suppressed. She is married to Michael O'Malley, "an alcoholic and passionless husband, bullied and emasculated by his powerful family (Hoyt 64). Michael "substitutes drink for sex" (Moore 11); he is a "frigid" man who never cares or talks about "love-making" and suffers from his "lack of potency" (O'Faolain 155, 249). Grainne mentions that "sex had been of such minimal importance in her marriage" (249). Seeing that she must resolve the matter and get rid of her unbearable situation, Grainne tries to violate the male, dominant order. Weekes explains that "within the country, as within women themselves, uncertainty, perhaps the residue of another order, stirs" (181). Grainne, therefore, resorts to James who knows well how to make her feel she is a woman. He is "awakening sensations where no sensation had been, livening areas of her secret flesh, causing a whirr and cascade, and unraveling" (O'Faolain 207). If Michael offers Grainne "only a half-life". It is 


\section{مجلة وادي النيل للاراسات والبحوث الإنسانية والاجتماعية والتربوية (مجلة علمية محكمة)}

(ISSN : 2536 - 9555)

James who gives her "fulfilling sexual relationship", a complete life, something "so long denied women in Ireland" (Weekes 186,187).

Unfortunately, Grainne's attempt to escape with her lover, James Duffy, is forestalled by the societal order since James is killed and the dream dies. However, Weekes, optimistically in her "Diarmuid and Grainne Again", believes that "despite the loss of James, Grainne has experienced existential freedom...she, and the country by implication, can proceed to define herself" (101).

Having approached Grainne in terms of womanhood, and seen her as somewhat successful, let us now approach her in terms of motherhood and see how far she is successful in this respect. Grainne's relationship with her son, Cormac, is more discord than accord.in terms of motherhood, and in comparison, to all the other mothers I have mentioned above, Grainne is not insightful as a mother though she is as a woman. Throughout the story, there does not appear to be any moments of maternal warmth on the part of Grainne towards Cormac. We only find dissent and sometimes repulsion: "lots of women liked being with children. It made them feel fulfilled. It made Grainne feel useless and used up like a ruff of old blossom drying in the dimple od an apple" (O'Faolain 57). In return, Cormac, whose "words were as solid as bricks" doubts Grainne as a good mother: "stop pretending to be a good mother. You re not. You took me to live with daft zombies... you must be mad. You live in the world, don't you? I don't want to have a mad mother" $(85,110)$.

As a fourteen-year-old boy, Cormac finds that "his mother was the flighty one. Certainly, it was she who had started people gossiping, and Cormac had to put up with fellows too big to fight asking him had she had it off with English fellows on the q.t. and would he maybe having a little English half-brother one of these days." (115) Under these circumstances, Cormac "wondered what it would be like to have a family" (104), and he begins "feeling like a martyr whose bones lay scattered on Alpine mountains cold ...the martyr image was closer. Cormac had felt dismembered. 
Mid-terms spent with his mother...had been unspeakably worse. He never ever wanted to think of them again. (O'Faolain 104)

As much as Grainne finds in James a vent for her repression, Cormac must search for his vent: "one way to deal with his mother would be to complain about her to Uncle Owen Roe" (O'Faolain 118). Sold to the satanic Rowe, like Dr. Faustus's spirit, no matter who is the seller, Cormac is now a fertile soil, well-prepared to receive the instructions of Patsy, the discipline of the satanic Rowe: "stand ye now for Erin's glory" (183), and adds: "now listen, Cormac, you have a responsibility to restrain yer Mammy if you can, and, if you can't, you should keep a close eye on her....women like your mammy, Cormac... are a menace. They're security leaks. Looking for attention. They've no sense" (184).

Cormac is also ordered by Patsy to frighten Judith, who is fractured like Ireland: "do you think you could frighten her a bit, Cormac? Would you be up to that? Just to try to get her to keep her gob shut?" (185). And, "just you keep your eye on your womenfolk and we'll count that as your good deed for the cause. Ok? 'Right you are,' said Cormac." (186). Cormac, now the victim, will be the predator tomorrow. Like many young Irish men, he escapes to the unknown. But the question remains: who sold Cormac's soul to the satanic Rowe? Who offered him as a sacrifice at the altar of the insatiable goddess, Ireland? I think it is his bloodmother, Grainne, who cares much more about her womanhood than her motherhood. The following questions may make things clearer: did Grainne do like Cal's mother who did everything she could do? Did she, like Cal's mother, deny her body when what she wanted was spiritual? Was Grainne behaving like Willie's mother with whom Willie "enjoyed it when we sat together at the oval table in the drawing room"? Was Grainne doing like Caithleen's mother who "was always a warrior...the best mama in the world"? Again, was Cormac as close and identified with his mother as Caithleen had been with her mother in The country Girls Trilogy? I do not think he was either. 


\section{مجلة وادي النيل للاراسات والبحوث الإنسانية والاجتماعية والتربوية (مجلة علمية محكمة)}

(ISSN : 2536 - 9555)

Though Grainne is a victim of the patriarchal order which devastates women, and though she does all she can do for Irish womanhood and partially succeeds, she, unfortunately, is more responsible than anyone else for Cormac's escape. She should have realized that a mother is the oracle of wisdom, the dispenser of values and the protector of children. She tries to keep him away from the meetings of the I.R.A., but it is too late. The wheel of fire is still running, swallowing the land, the mother and the offspring, consequently, the future of Motherland is completely undermined.

Coming to Willie's Motherland and blood-mother in Trevor's Fools of Fortune, we find that Ireland is still living the same miserable circumstances as it always has been. Willie tells us that "the city had been badly damaged in the fighting; half of Patrick Street was gone, shops and buildings blown apart by The Black and Tans" (Trevor 47). In Ireland, Irish children are "ragged creatures, dirty and barefooted" (48). This, in general, is part of the harsh reality which the innocent Willie has never known before the tragic raid upon his paradise of Kilneagh, the raid in which the whole meaning of his life rips away: the burning of Kilneagh, the death of father and sisters, and consequently the grievous suicide of mother all are sacrificial victims at the altar of the mad goddess Ireland. If Adam was driven away from paradise by eve's insinuations, Willie is "driven from his home [paradise] by violence" and also by Eva's promptings to her son to kill Rudkin (Hildebidle 124).

Willie has learned about the folly of war from Father Kilgarriff, and after a short while, war and violence have become savagely materialized in front of his eyes: "death...occurs very nearby, not in some distant battlefield" (Hildebidle 121). Though Willie and his mother survive the ordeal imposed upon them by the eternal curse of Motherland, the "effects on the survivors cannot escape" (Morrissey 59). Under these agonizing circumstances of Motherland, Willie's blood-mother falls down. Eva, who is English by birth, has become Irish by spirit. Thinking Irish, she earlier says, "I wish the rising had succeeded that Easter" (Trevor 21). Interestingly enough, "it is Willie's father who moderates his 
wife's enthusiastic support of Michael Collins' (Larsen 260). In support of the revolutionist Michael Collins, she is of the opinion that "if he ordered assassinations there was justice in what he ordered" (Trevor 32). At home, she is the major source of comfort, happiness, and control: "it was she who really made the decisions and presided over the household with untroubled authority (21, $15)$.

After the massacre at Kilneagh, Willie's blood-mother turns out to be a reflection of Mother Ireland: a victim of mere fortune, destroyed, alcoholic, and full of rage. Ironically, Eva, the English woman by birth, drinks the same poisonous cup her countrymen have been offering to Ireland for about eight centuries. The mother Eva, emotionally unable to bear the horrible memory of Kilneagh and escapes to drinking, full of resentment and desire for revenge, the fractured mother keeps reminding her poor son of Sergeant Rudkin who carried out the massacre: "I cannot understand why nobody shot him. I cannot understand that, he'd be back in Liverpool now, selling people vegetables" (Trevor 56). Eva describes Rudkin as "the Devil incarnate" (67). She asks Willie if he could visualize Rudkin in his vegetable shop, selling produce to people who didn't know he had been responsible for a massacre: "I often think about sergeant Rudkin. Well, I suppose you do too" (91). Larsen points out that "even after the murder of her husband and daughters, Eva could not renounce the use of force to resolve conflicts" (260). Thus, her happy and secure past life has given way to a new, grim, and unbearably tormenting existence. Willie's mother "slowly killed herself with hatred. Bitterness and despair" (Larsen 260).

Willie, an innocent, dreamy boy embodies "kindness itself", unlike Cormac, as his mother describes him (Trevor 61). Also, unlike Cormac, Willie maintains strong and loving relations with everybody and everything in Kilneagh, his lost paradise. Contrary to Cormac who "never ever wanted to think of ...mid-terms spent 


\section{مجلة وادي النيل للاراسات والبحوث الإنسانية والاجتماعية والتربوية (مجلة علمية محكمة)}

(ISSN : 2536 - 9555)

with his mother," Willie, the little "straw-haired boy... had no wish ever to leave Kilneagh". Since he believes that his life is there.

I know that one day I would inherit this mill. I liked the thought of that, of going to work

there, of learning what my father had to learn about grain and the machinery that ground it...

I loved the smell of the place, the warm dry smell of corn, the cleanness even though there

was dust in the air. I enjoyed watching the huge wheel turning in the mill-race, one cog

engaging the next. The timber of the chutes was smooth with wear, leather flaps opening

and falling back, then opening again. The sacks had Quinton on them, the letters of our

names arranged in a circle. (Trevor 17-18)

This kind of life, with its purity, serenity, and superior and loving family relations, is completely devastated by the ominous attack of Black and Tans. Schirmer clarifies that "the impingement of political and religious fanaticism, with its roots in Ireland's long divisive history, on the peaceful world of Kilneagh destroys the innocence of the young Willie" (149).

The process of Willie's dislocation starts, and the little boy with his "Edenic memories" comes to face the untimely harshness of his Motherland: "it is a long way from these Prolapsarian memories...to the nightmare world of everything that descends on Williie from the time that Kilneagh is burnt to the ground" (Schirmer 150). The darkness of Willie's life with his broken alcoholic mother is now removed by a faint beam of light as he falls in love with his English cousin, Marianne. This love creates some hope that Kilneagh's past life can be restored one day. Willie could have succeeded in overcoming his griefs and regaining his past life.in an interview, Trevor states "the idea of youth's resilience runs through the first quarter of fools of fortune", and 
adds that "Willie can recover from such an awful experience as the fire, whereas his mother can't, and she hasn't really lost more than he has lost" (quoted in Loughman 90).

Celeste Loughman supports Trevor's statement by asserting that the "school boy tales of erotic fantasies replace the accounts of family history;" adding that "for Willie the horror has lessened" (90). True, this is evident in Willie's statement that "the image of the man, lighting his cigarette at the corner of a street, had faded away almost to nothing" (Trevor 91-92). Another claim about Willie's ability to overcome his agonies is given by Morrissey who believes that Willi's experience of being sexually abused by Miss Halliwell resulted in his knowing how "to respond coldly to those who abuse him" (58). But, unfortunately,, Willie's mother, who is as depressed and troubled as Ireland, kills herself. The helpless young man finds himself, like the heroes of Greek tragedy, confronted with events over which he has no control: "Willie has no choice but to be the avenger. His mother's words, both a curse and an obligation, extend the cycle of hatred and vengeance" (Loughman 91).

Motivated by his own griefs and guilt towards his mother, who was constantly prompting him to take revenge against Rudkin, and also highly thorned by guilt because he has made love to Marianne soon after burying his mother, Willie flees Ireland and kills Rudkin, fulfilling his hope which his mother had so long pined for. Together, the Motherland with its atrocities and the victimized blood- mother, with her unfaltering desire of vengeance, her incessant prompting of her son to take revenge, and her suicide, have pushed their poor young man to the fathomless abyss of loss and escape. Larsen insightfully points out that

Willie construes his mother's suicide as a silent commission to complete a pattern: Doyle's

Tongue was cut out, his mother cut her wrists with a razor blade, and so Rudkin must be 


\section{مجلة وادي النيل للاراسات والبحوث الإنسانية والاجتماعية والتربوية (مجلة علمية محكمة)}

(ISSN : 2536 - 9555)

Slaughtered with a butcher knife. Throwing over the years of preparation for the rebuilding

of Kilneagh in his father's stead, turning his back on Kilneagh and Marianne, Willie follows

his mother's example. To the curse of guilt and exile, he adds the self-imposed punishment

Of silence, cutting himself off, inwardly renouncing all ties to Kilneagh. (262-63)

The goddess Motherland is still avaricious, either devouring or expelling her people and, "original sins", as Morrison comments, "whether by Adam or Edward, mar the fortune of all, always and everywhere" (496). Mother Ireland is unfailingly perpetuating destruction and the fact remains that escape, "bitterness, retributive violence, alcoholism and madness appear to be the only alternative for those traumatized by the merciless history of Ireland (Morrissey 60). In Fools of Fortune, it is not only the younger generation who are lost: everybody is lost.

The third example of the lost young men is to be found in Bernard Mac Laverty's Cal. Cal's case is somewhat different from Cormac's and Willie's. The narrator tells us the story of a young man, Cal, who takes part in some of the I.R.A. operations and then quits. All attempts by his I.R.A. fellows to involve him back are resisted and the young man, despite the burning of his house by Protestant terrorists, does not return back to the I.R.A. and escapes peacefully. However, he is spotted by the police and falls, like Cormac and Willie, in the abyss of loss. Two questions must emerge: what are the reasons behind Cal's involvement? And why does he quit?

To deal with the first question we find that part of the answer is that Cal, like most of the young Irish men, was trying to defend his country against the British occupation, and also to avenge the Protestant terrorists. Another part of the answer is that Cal might have been greatly motivated by his state of being unemployed. Scanlan sees that "Mac Laverty emphasizes unemployment as a

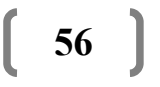


catalyst to violence" (151). Another part of the answer is that Cal might still have been highly influenced by his mother's "rebel songs" to him when he was young.

Why does Cal quit? Evidently, he quits due to his increasing guilt towards Marcella, whom he now loves and, whose husband was killed in an operation in which he himself had taken place. Watt points out that “ Mac Laverty's young protagonist, tortured by guilt over his participation in the assassination of Robert Morton, the policeman whose widow Marcella becomes the most important person in Cal's life, neither will Skiffington's allusions to Padraic Pearse and the events of 1916 justify the suffering endured by families like the Mortons. (132)

Ironically, if Cal's sense of guilt and love of Marcella have temporarily immuned him against loss, it is the same two reasons (though in different ways) which pushed Willie to escape and loss: Willie's guilt towards his mother's tragic death, and also his making love to Marianne immediately after burying his mother, have enhanced and accelerated his desire of vengeance and, consequently, his escape. Another reason behind Cal's shunning is that Cal might have seen himself as stripped of his Irishness, and that he is more like a Negro than a young Irish man: "He ...spoke to his image in a Negro voice" (Mac Laverty 51). Earlier, he began to chant a Negro work song in a thick American accent, striking the wedge at the end of each line:

Take this hamm-or

Carry it to the cap-tain. (47)

Watt asserts that "Cal more readily identifies with the world of black music than with that of nationalism constructed by Pearse's poem or "The Croppy boy," one of his deceased mother's favorite songs (132). Also, it seemed that Cal "ceased to believe" in Ireland, "An Ireland which never was and never would be" (Mac Laverty 92). Cal's blasphemy in his Motherland's madness 


\section{مجلة وادي النيل للاراسات و البحوث الإنسانية والاجتماعية والتربوية (مجلة علمية محكمة)}

(ISSN : 2536 - 9555)

shunned him from performing any more bloody rituals; he is no longer a prayer in the temple of fire.

Moreover, the grievous experiences which Cal has undergone (physical punishment by Protestant terrorists as well as the burning of his house, like Willie's) have also increased his immunity and detachment: "I have no stomach for it...But to kill a guy on his own door step?" (25). Ironically, Cal goes to work for the people whose son was killed "on his own door step". And what is more ironic is that Cal gains or regains a cleansing effect on the same place where he formerly lost it. Scanlan tells us that the Mortons farm "offers him a way of deferring involvement in the I.R.A." (151).

The process of Cal's dislocation starts after the burning of his house. Shamie, Cal's father, who once vows "no loyalist bastard is going to force me out of my home," is now forced to move and live with a cousin (Maclaverty9). Like Willie's mother, Cal's father "had aged twenty years in a couple of weeks... The flesh of his face had almost disappeared and what was left seemed to have slipped and sagged. He did not even smile when Cal came in" (123). Cal and Shamie, like Willie and Eva, lost their dear house. "I never knew how much I loved that house, that garden", Shamie said (123). More tragically, Shamie's image has become like that of the poor Motherland: "even his voice had changed, had lost all its strength. It wavered like the voice of an old woman feeling sorry for herself" (124). Shamie, who was "stubborn" earlier, is now broken like a woman, a poor mother (MacLaverty 9). Caithleen of The Country Girls Trilogy once expressed her sense of guilt towards her poor mother: "I felt guilty on and off, because I was happy with him [Gillard] and because I had seldom seen my mother happy or laughing" (O'Brien 20). Similarly, Maclaverty tells us that Cal "retained enough memory of Shamie's misery to feel guilty about being happy with her [Marcella]" (125-26).

However, Cal does not materialize his anger and depression into any kind of violence. Rather, he considers the ruin of his house as retaliation for his sin against Marcella: "in a way... it could be a

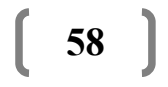


clean start. Like burning a wound to cleanse it" (Mac Laverty 90). Earlier before, Cal's mother, unlike Willie's or Cormac's, has taught him to "turn pain and sorrow into a gift for God" and now he does (Mac Laverty 117). He escapes peacefully to a cottage on the Mortons' Farm. The place which he and his I.R.A, fellows once turned into a hell ironically turns out to be his heaven. There, "he got a sense of a new life, a new start" (117). But, if Cormac has escaped to the fanatic Ireland of I.R.A, and Willie, the protestant, to Italy, the Motherland of Roman Catholicism or let me hazard by saying the spiritual Ireland, Cal escapes to the real Ireland, the "pastoral Ireland" (Watt 135). On the farm, Cal regains the meaning of life which he lost long ago: "The Morton's cottage and Cal's brief affair with Marcella constitute an alternative ground or emancipatory locale as well...the Morton farm thus becomes a site of transformation" (Watt 145,146).

Sorrowfully, if his past sins are to be repaid, Cal has to pay forever. The poor young man is enforced by Crilly to attend an I.R.A. meeting (like those which Cormac attends willingly).during the meeting, he learns that a bomb was placed inside the library where Marcella works. The meeting is suddenly attacked by the police and Cal succeeds to escape and, out of retaliation, he informs the authorities about at the bomb before going back to his peaceful cottage. Since his retaliation is not yet completely fulfilled - today is his last day on the farm, and tomorrow he will be in the unknown. The police arrive the next day to arrest him. The poor Cal has to join the long line of the lost young men.

In the two cases of Cormac and Willie, blood-mothers have acted as intensifiers to the endless course of loss, which the Motherland has always been imposing and mercilessly practicing on the young Irish men. The land and mothers together in one cloak, that of Cathleen ni Houlihan, have, in the absence of heavenly lambs, slaughtered their helpless Isaacs. Providence has nothing to do in the land of Rowe, Rudkin, Skiffington, and Crilly. Cal, on the other hand, was not more fortunate than his 


\section{مجلة وادي النيل للاراسات والبحوث الإنسانية والاجتماعية والتربوية (مجلة علمية محكمة)}

(ISSN : 2536 - 9555)

counterparts. Ironically, he was also victimized despite the nonexistence of the mother, the intensifier. But the point is that had Cal's mother been alive and experienced the horror of the burning of her house, like Willie's mother, she could have surely prompted her son to take revenge, despite her ideal of turning "pain and sorrow into a gift from God" (Mac Laverty 117). Though Cal's father survived the burning of the house, and though his image turned out to be like an "old woman feeling sorry for herself" (124), he did not prompt Cal to take revenge. And, if the father had done so, Cal might not have responded, simply because mothers almost always have a greater influence on their boys than fathers.

\section{Works Cited}

Cahalan, James M. "Female and Male Perspectives on Growing Up Irish in Edna O'Brien, John McGahern and Brian Moore." Colby Quarterly 31.1(March 1995): 55-73.

Creel, George. Ireland's fight for freedom: Setting Forth the High Lights of Irish History. New York: Harper, 1919.

Deane, Seamus. "Introduction". Nationalism, Colonialism, and Literature. By. Terry Eagleton, et al. Minneapolis: U of Minnesota P, 1990. 16, 17.

Fitzgerald-Hoyt, Mary. "The Influence of Italy in the Writings of William Trevor and Julia O' Faolain." Notes on Modern Irish literature 2 (1990):61-67.

Hildebidle, John. "William Trevor's Two Nations." Erie-Ireland: A journal of Irish studies 28.3 (Fall 1993): 114-29.

Innes, C.L. Woman and Nation in Irish Literature and Society, 1880-1935. Athens: The U of Georgia p, 1993.

Kibred, Declan. "Irish Literature and Irish History." The Oxford Illustrated History of Ireland. Ed. R. F. Foster. Oxford, NY: Oxford UP, 1989. 
Larsen, Max Deen. "Saints of the Ascendancy: William Trevor's Big House Novels," Ancestoral Voices: The Big House in AngeloIrish Literature. Ed. Otto Rauchbauer. Hildesheim, NY: George Olm Verlag, 1992: 260,261.

LIoyd, Richard Burr, "The symbolic Mass: thematic Resolution in the Irish Novels of John McGahern." Emporia State Research Studies 36.2 (Fall 1987):5-23.

Loughman, Celeste. "The Mercy of Silence: William Trevor's Fools of Fortune." Eire-Ireland: A Journal of Irish Studies 28.1 (Spring 1993): 87-96.

Mac Laverty, Bernard. Cal. London: Jonathan Cape, 1983.

McGahern, John. The Dark. London: Granada, 1967.

Moore, Thomas R. "Triangles and Entrapment: Julia O'Faolain's No Country for Young Men." Colby Quarterly 27.1 (March 1991):9-16.

Morrison, Kristin. "William Trevor's System of Correspondences." The Massachusetts Review Quarterly of Literature, the Arts and Public Affairs 28.3 (Autumn 1987): 487-96.

Morrissey, Thomas. "The Rape of Ireland." Notes on Modern Irish literature 2 (1990): 58-60.

O'Brien, Edna. The Country Girls Trilogy and Epilogue. London: plume Books, 1987.

O'Casey, Sean. "The Plough and the Stars." The Sean O'Casey Reader: Plays, Autobiographies Opinions. Ed. Brooks Atkinson. New York: St. Martin's, 1968. 63-131.

O'Faolain, Julia. No Country for Young Men. Bungay, Suffolk: Chaucer, 1980.

O'Flaherty, Liam. The Black Soul. Dublin: wolfhound, 1996.

-----, “Going into Exile." The Short Stories of Liam O' Flaherty. Kent, England: new English Library, 1986. 94- 103. 


\section{مجلة وادي النيل للاراسات والبحوث الإنسانية والاجتماعية والتربوية (مجلة علمية محكمة)}

(ISSN : 2536 - 9555)

O'Toole, Fintan. "Island of Saints and Silicon: Literature and Social Change in Contemporary Ireland." Cultural Contexts and Literary Idioms in Contemporary Irish Literature. Ed. Michael Kenneally. Totowa, NJ: Barnes, 1988. 11-35.

Scanlan, Margaret. "Northern Ireland in Four Contemporary Novels." Etudes Irelandaises 10 (December 1985): 145-61.

Schirmer, Gergory A. William Trevor: A Study of His Fiction. London: Routledge, 1990.

Trevor, William. Fools of fortune. London: Penguin, 1984.

Vance, Norman. Irish Literature: A Social History; Tradition, Identity and Difference. Oxford: Basil Blackwell, 1990.

Vandale, Laura B. "Women Across Time: Sister Judith Remembers.” Colby Quarterly 27.1 (March 1991): 17-26.

Watt, Stephen. "The Politics of Bernard Mac Laverty's Cal." EireIreland: A Journal of Irish Studies 28.3 (Fall 1993): 130-146.

Weekes, Ann. "Diarmuid and Grainne Again: Julia O' Faolain's No Country for Old Men." Eire-Ireland: A Journal of Irish Studies 21.1 (Spring 1986): 89-102.

------, Irish Women Writers: An Uncharted Tradition. Kentucky, the UP of Kentucky, 1990. 